\title{
SAFETY AND RISK
}

\author{
PhD, Ing. Jerzy KOZIOŁ \\ National Defence University, Warsaw, Poland
}

\begin{abstract}
The problems related to the safety of human life are one of the most actual and crucial topics of the modern world. In an era of globalisation and substantially complicated conditions of social life, every human being needs to make a choice, which enables him or her to increase the possibilities of development and, at the same time, to ensure the safety of his or her own life as well other people's lives. Taking into account the technological and industrial development, scientists intend to decrease the level of risks in work processes. No matter the efforts, these risks cannot be completely eliminated. Thanks to certain knowledge, a human being is able to make a rational decision in an emergency with an accepted level of risk. As the experience shows, the main reasons of such emergencies are people themselves.
\end{abstract}

Key words: risk, safety, safety culture

In this article, I will focus on the problem of the codependence of risk and safety in the daily life of the modern man. I will show the correlation of those two categories, as well as describe the updated elements of the topic in a recent discussion about safety theories.

The main goal of this article is the analysis of the terms "risk" and "safety" in the area of their social and philosophical aspects from creation till modern times.

The main tasks carried out in this article are:

1. to define the terms: "safety", "risk", "society of risk", "safety culture";

2. to show the correlation between safety and risk; to summarise the recent theories of risk and safety;

3. to develop the term "safety culture". 
The significant increase of the influence of artificial regulators on the common, overall system "society-technosphere ${ }^{1}$-nature" is the crucial issue for the society of the twenty-first century. The attention of scientists, politicians and society is focused mainly on the essential matters of management associated with safe technologies and the re-organisation of the open society of risk ${ }^{2}$. What differentiates, the technological strategy of human activities in the twenty-first century from the preceding times is the other approach to new types of objects and processes, which implements complex, self-organised "macro systems". The most significant are the ones in which we operate as human beings, separately from other systems. Hence, the opposition: "man vs. machine", which develops in a bigger, dynamic system: "human- technical system - technosphere"; a system, in which, when we talk about the embedding of new technologies, we must take into account the cultural conditions of the surroundings. Research in the area of the safety theories ${ }^{3}$ shows that, in the self-organised, open "macro systems", we deal with informational cooperation, rather than a physical one. As a result of this cooperation, the complex systems might create the new structures without any physical impact. Those kinds of "macro systems" generate the processes of selforganisation characterised by non-linear dynamics and synergy. We have to take it all into consideration when we develop the new, effective ideas for our safety ${ }^{4}$.

\section{Conceptualisation ${ }^{5}$ of "safety" and "risk"}

Before we begin, we need to agree upon the definition of the term "safety". According to the Polish Dictionary of National Safety Terms, the term "safety"

1 Technosphere: The sphere or realm of human technological activity; the technologically modified environment. Oxford Dictionary of English.

2 U.Beck, Społeczeństwo ryzyka. W drodze do innej nowoczesności, SCHOLAR, Warszawa 2002, s. 28.

3 P. Sienkiewicz, Bezpieczeństwo i obronność na przełomie XX i XXI wieku [w:] Praca zbiorowa, Nauki Wojskowe a nauki o obronności, AON, Warszawa 2009, s. 118.

4 K. Raczkowski, Ł. Sułkowski, Zarzadzanie bezpieczeństwem. Metody i techniki, Difin, Warszawa 2014, s. 16.

5 Conceptualization - 1. The action or process of forming a concept or idea of something;

2. An abstract idea or concept of something. Oxford dictionary of English.

6 J. Gryz, Strategia Bezpieczeństwa Narodowego Polski, PWN, Warszawa 2013; W. Kitler, Bezpieczeństwo narodowe RP. Podstawowe kategorie, uwarunkowania system, 
(pol. bezpieczeństwo) is a state which gives the feeling of protection and the guarantee of its preservation and a chance for further development. It is one of the basic needs for a human being. Its main characteristic is the lack of risk of losing something very dear to us, e.g. health, job, respect, feelings, tangible goods. Among the different types of "safety", it is worth mentioning: global, regional, national safety; military, economic, politic, public, social safety; physical, mental, structural and personal safety ${ }^{7}$.

Safety can also be described as a total of the necessary and sufficient factors, which assures the dignity of every human life. However, the essential condition of man's existence is activity, which includes practical, intellectual and spiritual processes during the human being's journey, as well as social, cultural, political and scientific pursuits. The model of the processes of life activities can be presented in a most general way through two basic elements: a human being and the environment in which he or she lives. These two elements are correlated. This relation is conditioned through the general law of reaction: one goal results in achieving a certain effect in an activity process; to put it in another way, nature reacts to man's behaviour from two different perspectives. On the one hand, for hisdaily existence, a man must secure the stability of all the elements of his environment, like temperature, air pressure, humidity, radiation's level etc. Without this control, all the mentioned elements might be hazardous for the human body. The increasing role of ecological movements in the political sphere of many countries shows how crucial those elements are.

On the other hand, though, human activity is not possible without a destructive impact on the nature. The mineral-extracting; ground, water and air pollutions, or the liberation of excessive heat; that is just a small part of the "results" of human activity dangerous for the environment ${ }^{8}$. Every coin, just like the correlation between man and nature, has two sides.

The problems of safety are researched in the framework of safety theories, independent scientific analysis as well as tasks of social practice. The direction

AON, Warszawa 2011; K. Raczkowski, Ł. Sułkowski, Zarzadzanie bezpieczeństwem. Metody i techniki, Difin, Warszawa 2014, s. 20-34.

7 Stownik terminów z zakresu bezpieczeństwa narodowego, AON, Warszawa 2008.

8 U. Beck, Społeczeństwo ryzyka. W drodze do innej nowoczesności, SCHOLAR, Warszawa 2002, s. 74 . 
of this research might be compared with the works concerning conceptualmethodological problems of risk. The analysis of the important issues concerning the management of safety and risk, its challenges, threats and hazardous situations, have a special impact on the continuation of the research ${ }^{9}$.

Of course, if we want to organise the research instruments on the subject of the safety problems, we need to enter the philosophical sphere of ontology. Ontology is the branch of metaphysics concerned with the nature or essence of being or existence $^{10}$ - subjects or occurrences, which, as a result of the interpretation, through language, create knowledge. The importance of ontology assumptions determines the attitude of a scientist and implicates adaptation of certain gnoseologic presumptions with regard to the recognition of the reality and its subject - the pure knowledge ${ }^{11}$. On the other hand, the gnoseologic presumptions influence determined ways of scientific research; hence, the methodology. Through our philosophical matters, we also need to take into account the axiologythe branch of philosophy dealing with values, as those of ethics, aesthetics, or religion ${ }^{12}$.

From the ontological point of view, every object is always in danger. Every object is constantly under risk, because threat is not a phenomenon per se, but rather a specific state of relations and contacts of a specified object with its surroundings. In nature, though, there are no objects whatsoever which are not involved in the net of relations and contacts ${ }^{13}$. Hence, there is no object which is absolutely safe. So, we can accept, from a gnoseologic level, that the knowing (assuming) subject analyses and constitutes, in language, the unrealistic position of the object (in semiotic terms- denotation ${ }^{14}$ ) and its reflection in its conscience ${ }^{15}$. It is known, however, that this reflection is not always full and credible. This means that we cannot know everything about the state of the object, or about its relation and

9 A. Giddens, Stanowienie spoteczeństwa. Zarys teorii strukturacji, Zysk i S-ka, Poznań 2003, s. 67.

10 Farlex Trivia Dictionary (translator's note).

11 Ibidem, s. 172.

12 British Dictionary of Philosophical Definitions (translator's note).

13 Ibidem, s. 39.

14 D. Chandler, Wprowadzenie do semiotyki, Oficyna wydawnicza VOLUMEN, Warszawa 2013, s. 47.

15 L.J. Krzyżanowski, O podstawach kierowania organizacjami inaczej..., PWN, Warszawa 1999, s. 191. 
contact with other objects, because we know that our assumptions do not always correspond with the reality. Moreover, rational recognition goes hand in hand with the sensual experience of the recognised reality of the subject. Safety is also a sensual experience, based on probabilities and mathematical calculations, as well as on our psychological reactions to risk. In a more general sense, we can be secure, even if we don't feel like it. Also, we can feel safe, even if we are not ${ }^{16}$. In the language of science (logic), we can say that the knowing subject nominates (in terms of semiotics) as dangerous or safe not a situation but the attitude toward it. This attitude might be formed based on a) the reflection of the reality (significant) ${ }^{17}$ b) feelings and emotions, which don't exactly reflect the situation, but rather the mental state of the subject (connotation) ${ }^{18}$. To put it another way, safety presents itself as one individual's certainty about the stability (resistance) of the (social and natural) order around, as well as the accordance of certain reactions between the human expectation and the world. It is a paradox that tsafety doesn't actually mean the total lack of hazardous situations.

The human practice allows us to claim that every activity is potentially dangerous (the so called "axiom about potential danger"). The collaboration between man and his surroundings is a topic which does not apply only to one's scientific research. If we accept that danger and safety are created through the processes of correlation between objects and their environment, it is correct to use the system's approach.

Even if our research only touches the surface, it is obvious that the assumption about the (non) existence of danger concerning the „object” might proceed only on the basis of the analysis of all the information related to the process: from the goals, possibilities, interests of the „subject” and its „environment”, which consists of other subjects, objects of (in)animate nature, natural occurrences; to the "object" itself, its possibilities, reactions etc., channels of communication, their types and states, as well as the presence/absence of the systems of counteracting (defense). From this perspective, we might say, that "danger" and "safety" cannot

16 R. Klamut, H. Sommer, K. Michalski, Aktywność obywatelska we wspótczesnym społeczeństwie demokratycznym. Wybrane zagadnienia, Seiton, Kraków 2010, s. 86.

17 D. Chandler, Wprowadzenie do semiotyki, Oficyna wydawnicza VOLUMEN, Warszawa 2013, s. 48-50.

18 Ibidem, s. 47. 
be treated as a "state". It is methodologically correct to treat it rather as a "situation", which means the connection between conditions and circumstances, which form a certain, ordered position. The last issue that must be cleared up is the question: which situation would be considered dangerous or safe in the mind of the subject? In this case, there are three possibilities of identification and nomination:

1. The subject makes an assessment of the situation and, on the basis of it, he or she forms (generates) conclusions about safety or danger. The result generated nomination of safety

2. The subject assesses the position of the safety object, which means the safety subject stands in opposition to the safety object ontologically. In this case, the safety subject creates its own subjected opinion about the safety object. The result- projected nomination of safety.

3. The subject is forced to accept the different point of view, the opinion forged by the other subject (perhaps, one that doesn't correlate with reality). In this case, the subject and object of safety are not bound between themselves ontologically, but gnoseologically, through another subject(s). The resultinduced nomination of safety.

Of course, the assessing subject, who sees danger, will take into account everything that might bring harm to the safety object. To put it another way, danger is an indication of the situation, where the probability of $t$ harm, from the perspective of the assessing subject, is bigger than from the certain, subjective border created by the same subject. Hence, a safe situation takes place when the subject assesses the possibility of damage as irrelevant. Then, the question we should ask is: what are we supposed to understand, as "damage"?

Damage is a result of the impact which appears after unwanted or unnecessary implications for the impact's object.

What is the object/subject is interested in? We cannot say. However, we are able to set the unwanted consequences: 1) Loss of life or health; 2) Loss of freedom; 3) deterioration of life conditions. Nowadays, in the era of information, we can not only lose our freedom to act, but also our freedom to think rationally, with the requirements of our own businesses focusing on self-development. This is possible thanks to the great accomplishments of modern science and technology. 
The management subject ${ }^{19}$, without any restriction on actions, through the manipulation of data, forging of the necessary ideology and introducing a changed image of the reality to the consciousness, exposes the management object (certain individuals, a group, citizens of a country, millions of people on Earth) to uncertain results of his/her shadowy actions according to his/her (the management subject) will. As a result, the management object is sure that its actions will bring benefits to itself. Meanwhile, these go to the management subject. It is worth mentioning that the disclosure of the real management subject is very complex. Normally, the management subject does not show its possibilities and actions, trying to hide its true intentions. Though this is exactly the key task which will ensure the safety of the object - to identify the true management subject, who is a main source of the danger; its goal and capabilities.

It is important to explain what the object understands as an "unfavourable result" and what we suppose to understand as such. We comprehend it as a destruction of the structural unity of the object as well as a dysfunction of its homogeneity.

One of the specifications of the instability of the system (or individual, organisation, nation, etc.) is the extra use of the energy which the system requires to apply to go back to its initial state, instead of spending it on its development. Instability might lead to destruction, when the impact parameters are bigger than the border parameters of system resistance. It is worth mentioning that instability, which is often associated with danger, is nothing more like a very special case of dysfunction. It does not always create damage; hence, it does not always produce danger.

Damage can be produced not only through the direct impact on the object, but also indirectly, through other objects in its environment, as a result of the change between its relations and contacts, reduction in its stability and the potential of the goals it supposes to reach. Therefore, damage is a result of the action, which shatters the functional unity (destruction) of the object, its existence conditions or its potential to reach goals focused on self-development.

19 Management is a process of free or forced limitation of freedom to act with the goal of achieving a group success. The essence of the process is a coordination of individual and group action, submitting them to the purpose. The known forms of management are: command, conduct, administrate, rule etc. 
It is known that "damage" (just like "benefit") cannot be absolute; what brings damage to one object is beneficial to another. It all depends on the parameters of the actions, the object's characteristics and the judging criteria. Though in the social system there is only one, just criteria for all of its elements, which is the self-benefit of the system. If not, there is no point in its existence any longer. If the benefits of the separate elements of the system are more important than the benefits of the system as a unity, sooner or later it will be doomed to extinction.

Just one more important conclusion: the biggest danger for the safety object is created by itself. It might seem confusing when we look at it for the first time, but it becomes obvious when we analyse the certain case when the safety object is also its subject. Every action of the „subject” changes its relations and contacts with the environment, which might bring the deterioration of the condition of its existence, decrease of its potential to reach the goal or its destruction and dysfunction. This is what we call a "risk".

Risk is an attribute of action, which, as result, might bring harm. The existence of risk depends mostly on the certainty or uncertainty of the final results. To take a risk means to take action, which might bring harm to the acting subject. This means that every change in the environment might be potentially dangerous for the subject/object of safety and every action has a risk in it. Threat and risk can be identified as a danger, if the damage that they create is bigger than the one assessed by the subject. Threats and risk enforce danger from the different vectors: risk is based on a subject but it is directed towards its surroundings, meanwhile threat is rather based in our environment but it is directed toward the subject. The vectors directions are opposite, but they might bring the same results: harm to the subject. Source and motives are different, but the conclusion stays the same. This is the main reason for methodological and terminological disorder, concerning those two terms. It also enables us to reach the conclusion that the risk theory is, at the same time, a special form of the safety theory.

In literature, we might come upon different theories about the essence of risk. Some of them are not specific enough to be adequate for use in social practice and in management tasks ${ }^{20}$. It is well-known that risk is a complex term, which

20 T.T. Kaczmarek, Ryzyko i zarządzanie ryzykiem. Ujęcie interdyscyplinarne, Difin, Warszawa 2005. s. 64. 
has many, sometimes exclusive interpretations ${ }^{21}$. In this article, we will have a closer look at social points of risk, which might unite its different characteristics and theories into one; therefore, it will help in a better understanding of the phenomena of modern science. It is worth mentioning that the term "risk" and its meaning have been changing, depending on the stage of the development of human society. The objective understanding of the essence of risk is connected with the randomness of many processes and variability of social contacts. That is why it is so hard to describe many social behaviours unambiguously. Moreover, risk is connected with randomness, which sometimes might be decreased or even eliminated.

In t Ancient Egypt and Greece, risk assessment was used mostly to help with gambling. We can still find the proofs of gambling scenes on Egyptian tombs and Greek vases ${ }^{22}$. However, danger and insecurity about the future was rather connected with the higher powers and gods. The scientific interest in the problem of probability of negative or positive happenings has a long story. If we focus only on European sources, we can already find the first questions about the idea of correctness, coincidence and uncertainty in Homer's or Herodotus' work ${ }^{23}$. But those ideas had to deal with cyclical development, human and cultural society. This is why, in mythological ideology, the relationship between the actions of individuals and its results was not formulated or known.

During the Middle Ages, in Europe, we can come upon the word „risk” among the written sources,, but it only became common at the beginning of the era of print (around 1500), especially in Italy and Spain ${ }^{24}$. The term was used in many different fields. For example: see insurances- one of the first cases of planned control of risk. There is a theory that the new word "risk" was used to describe a problematic

21 Ibidem.

22 A. Chyliński, Podgladanie ryzyka. Dyktat zatożeń, PWN, Warszawa 2015, s. 47.

23 The Histories a historic book, written by Herodotus. The construction of The Histories is a complex system of digressions, complementing themselves. As a source, Herodotus used his own observations, oral tradition of different tribes and preceding literature. Sometimes, he presents the same story from a different point of view, so the reader is able to choose the version he likes the most. Oracles and signs sent from gods have a great part in it, as human history is ruled by gods' rights, which punish those who enjoy too much success in life. It is similar in Homer's Illiad; concurrently to the humanworld, (profanum) exists the gods' world (sacrum), which has a huge impact on the heroes' actions.

24 N. Luhman, Pojęcie ryzyka, Thesis. Ryzyko. Nieokreśloność. Przypadkowość. 1994, nr 5. 
situation, which could not be described with already known words like: "danger", "courage", "accident", and "fear" 25.

The English word "risk", the same as the Polish ryzyko, comes from French (risque - danger). The French word, though, comes from the Greek rizikon - a rock; that is why "to risk" for Greek sailors meant "to course along the rocky, dangerous coast", to avoid disaster ${ }^{26}$ The other approach to the etymology of the word "risk" comes from Spanish (risso - „vertical rock”) and Italian (risiko - „danger”, „threat”; risisare -"to dare"). As we can see, in both cases, "risk" meant possible danger. The meaning did not really change till nowadays.

In the Oxford Dictionary of English ${ }^{27}$ "risk" is described as: a person or thing regarded as likely to turn well or badly in a particular context or respect, a situation involving exposure to danger. To risk - 1) act in such a way as to bring about the possibility of (an unpleasant or unwelcome event); incur the chance of unfortunate consequences by engaging in (an action); 2) expose (someone or something valued) to danger, harm, or loss., and so on: "at one's own risk", taking responsibility for one's own safety or possessions".

For better understanding of the first meaning of the term, it is worth mentioning that the main object is a subject, whose actions are uncertain but with hopes of succeeding. Moreover, the actions are caused by the subject's emotions (courage, decisiveness), which enable its willingness virtues. The second meaning shows that the result of the action might be 1) failure or 2) luck. In the first case, we underline the probability of failure (the risk level). In the second one, the stability of the positive results of the action (what the risk is all about). The mentioned description reflects the ambiguity of the term, still not clear enough. Moreover, the risk is identified with the quality, appropriated for the subject or the characteristics of the actions that occur, detailed by the presence of certain social qualities.

In English scientific literature, in the works of Adam Smith, for example, there was vast usage of the word "hazard”; meanwhile the term "risk" („risque") was introduced around 1830 in insurance operations. During the rest of the nineteenth

25 J. Kozioł, Ryzyko decyzji w zarzadzaniu kryzysowym [w:] J. Piwowarska, Funkcje teorii nauk o bezpieczeństwie, Wyższa szkoła Bezpieczeństwa, Kraków 2014.

26 N. Luhmann, Risk: A Sociological Theory. N-Y.: Walter de Gruyter, Inc., 1993.

27 Oxford dictionary of English,, Warszawa 1981. 
century both terms had the same importance and only in the twentieth did the word "risk" get ahead of its rival in economic literature and real practice ${ }^{28}$. The lexical ambiguity of the term is already quite obvious: from one hand, "risk" is a "potential danger"; on the other hand it is an action with an uncertain result, but with hopes for the best". There is a clear line between the positive and negative meaning of the word. At the same time, the term "risk" is directly connected with the dichotomy "danger-safety".

It seems obvious that the phenomena of safety cannot be researched without analysing its opposite danger. The two elements of the clash cannot exist without each other. This is well-illustrated by the etymological approach. Moreover, "safety" (sicherkeit bezpieczeństwo) cannot be treated as the beginning of the research, as it contains the negation of what it cannot exist without - a danger (unsicherkeit niebezpieczeństwo). The negative cannot precede the negation. "Safety" derivatives from "danger", so the approach to analysing "safety" without finding its underlying cause- "danger" will give us as an unlimited number of variations.

The etymological analysis proves that the word "risk" appeared and was originally used to describe danger that might come upon the subject (fear before drowning, the possibility of danger or failure), and also to describe its emotional state: its courage, faith and hopes for better (the courage to cruise along the spiky rocks, to hope for a bit of luck). According to that, the probability of risk bringing negative or positive results for the acting subject is the same. This is why the term is so ambiguous from the lexical point of view.

The term "risk" is becoming one of the central expressions among modern safety theories. However, it was changing its meaning throughout human history. Its entrance into politics decreased its connection with technical calculations of probability ${ }^{29}$. Going back in time, we might see that the term gained its position in Europe in the seventeenth century, in connection with gambling. What did risk mean at that time? The probable appearance of a certain happening, in combination with the sum of win or loss. In the seventeenth century, the probability

28 A. Smith, Badania nad natura i przyczynami bogactwa narodów, PWN, Warszawa 2007.

29 U. Beck, Spoteczeństwo ryzyka. W drodze do innej nowoczesności, SCHOLAR, Warszawa 2002, s. 83. 
analysis became a basis for scientific knowledge, changing forever the character of authority, reality and $\operatorname{logic}^{30}$. In the eighteenth century, the risk analysis had an important practice in sailing insurance. The chance of a ship returning safely to its home harbour, bringing gains to its owner, was set against the chances of its sinking into the sea, which would bring losses, of course. The whole idea of risk was based on calculations: probability of gains and losses ${ }^{31}$. The risk theory in the nineteenth century played an important part in the development of economics. People took into account that many incidents happen independently from risk, as it was assumed, some made their choices not according to the probability of risk, but rather hedonistic ${ }^{32}$ calculations. To take a risk, the owner of the company needed proof of its possible success. Otherwise, he was not willing to invest his capital. Every process and every action has a probability of success or failure. The risk calculations are well-grounded in science and production, as well as in every decision making theory. It was the probability theory that, in many cases, created the oath for modern thinking ${ }^{33}$.

The huge progress in understanding the connection between randomness and predictability was made during the twentieth century thanks to the synergetics ${ }^{34}$, which show that randomness is neither a result of the complexity of the system nor a consequence of different purposes. The key to this one stands in the fact that the more complex system we have, the more dependable it is to the initial conditions, which brings it to its instability. It is the unstableness which is a main characteristic of many systems, both, simple and complex ones ${ }^{35}$.

30 P.L. Brenstein, Przeciw bogom. Niezwykte dzieje ryzyka, WIG PRESS, Warszawa 1997, s. $168-169$.

31 P.L. Brenstein, Przeciw bogom. Niezwykte dzieje ryzyka, WIG PRESS, Warszawa 1997, s. 81 .

32 Hedonism (gr. $\dot{\eta} \delta o v \dot{\eta}$, hedone, "pleasure") - the ethical theory that pleasure (in the sense of satisfaction of desires) is the highest good and proper aim of human life. The pursuit of pleasure; sensual self-indulgence. Oxford Dictionary of English.

33 P.L. Brenstein, Przeciw bogom. Niezwykte dzieje ryzyka, WIG PRESS, Warszawa 1997, s. 208-221.

34 Synergy (gr. „sin” - common, „ergos” - action) - The interaction or cooperation of two or more organisations, substances, or other agents, to produce a combined effect greater than a sum of their separate effects. Oxford Dictionary of English.

35 T. Kaczorek i inni, Podstawy teorii sterowania, WNT, Warszawa 2005, s. 97. 
Increased reaction to the initial conditions clearly shows the stability of a certain system; that the small, inner intentions might lead to surprisingly big results ${ }^{36}$. Synergetics showed that the attribute of the comprehension of initial conditions is specific for the rising number of social systems. Moreover, this peculiar ability of complex systems is a basis for the stable development of society ${ }^{37}$. It is necessary for the stable development of the system to change some of its characteristics, so some of its indicators would be manageable and, therefore, successful. This approach will also be useful for solving tasks concerning risk and safety management. For example, only the "subject" or "surroundings" might appear as a "source of danger". But we would never call as such "desires" or "trends". To put it a different way, the object/subject might be the "source of danger", but never the characteristics or processes. The process in which the safety object/subject takes part will only define the level of the danger that the mentioned object/subject is in. So, there is another important conclusion in our safety theory research: there is no such thing as safety in general. The only safety that exists is the specific one: the safety of someone or something.

The object (subject, system), whose safety is analysed must be isolated from its surroundings, identified and unambiguously characterised. Moreover, we should not examine a group of objects, but rather a certain individual one in a specific situation. Safety is something very specific, only the research method is universal!

In the twentieth century, the global problems became the basic source of unusual situations ${ }^{38}$ in a society of risk. This century was not only the century of the atomic

36 A condition that lead to the theory of chaos was in the research of Edward Lorenz on the models of weather forecasts. According to the reality in that time, the deterministic understanding of reality, the tiny change in the starting conditions should be conducted to the same, slightly different changes in the results of the model. During his work, as a facilitation to his research, he introduced the rounded, initial values. It turned out that the results of the model were enormously different to the data introduced into the same model with more precision. Further research brought the conclusion that, against all odds and theories that were widely accepted in scientific circles, a small alteration from the initial conditions leads to changes in a system's behavior decreasing in time.

37 OAt the present level of our civilization, stable development is possible. The main characteristic of such development is the fact that the needs of the current generation might be satisfied without reducing the chances of future generations achieving the same result.

38 Natural disaster might be a nature catastrophe or a technical breakdown, whose results put lives and health or many people, property of great value or the environment in a broad area in danger. 
bomb, space conquest or great, military conflicts. Surprisingly, the characteristics of our society have changed drastically. And with this change, the world became more "human" than ever. To put it in a different way, the new society has forged itself before our eyes. Its analysis allows us to see two, leading trends: the explosion of human activity and the globalisation of problems ${ }^{39}$. Of course, risk and danger are involved in both of them. Therefore, the risk measurements have also changed the way we perceive "the human factor". Until not so long ago, it was acceptable to think that catastrophes and unusual situations are something independent from people, "a twist of faith"; so something that was not in the hands of regular citizens, but rather a problem the politicians have to deal with. But, if we follow the idea of the stable development of society and we increase its safety to the maximum level, the people awareness is visibly changing. The main point is that one of the principle sources of dangers and risks, as the analysis of many catastrophes shows, is nobody else but a human being. It means that the solution to most of the global problems and the increase of our development is in our own hands. The change in human relationships and the understanding of risks is a key to our problems. The key trend in the twenty-first century in the development of society will be the creation of new, interdisciplinary approaches, which help solve the fresh-generated problems in risk management ${ }^{40}$.

Understanding the risk as a safety measure- is a very important step towards the solution to problems of situation management, in which factors that have an adverse impact on people, society and nature dominate. The way we understand risk today is combined within the probability of unwilling occurrence and the extent of possible damage or harm. Those two factors are always present in the subject's brain during its actions in dangerous conditions ${ }^{41}$. Through the comparison of the two factors, which reflect the complexity of the situation, the subject assesses the level of danger and he adopts the adequate solution to complete the task through risk management. The vast sense of the word "risk", in contemporary science and culture, is as general as the sense of the words "virtue", "justice" etc. The term is

39 U. Beck, Społeczeństwo ryzyka. W drodze do innej nowoczesności, SCHOLAR, Warszawa 2002, s. 126.

40 A. Chyliński, Podgladanie ryzyka. Dyktat założeń, PWN, Warszawa 2015, s. 143.

41 R. Holly, Zarzadzanie ryzykiem - czyli czym? [w:] red. W. Sułkowska, Rynekubezpieczeń. Wspótczesne problemy, wyd. Difin, Kraków 2013. 
used in many different fields of modern studies. It allows it to be divided into different types of "risk", for example a social-economic one.

Some of the basic safety objects are ${ }^{42}$ :

1) Individuals - their rights and freedoms.

2) Society-its material and spiritual values.

3) Country and its constitutional order, sovereignty and territorial unity.

The safety subject would be, in this case, a country, which implements legislative, executive and judicial functions on its territory; a nation (citizens), a society, or other organisation. To provide the direct security confidence for society and the country, the executive powers are allowed to create the public authorities to ensure the safety of the nation; the country secures legislative and social protection over the citizens, social institutions and organisations through assistance in providing safety with the applicable legal regulations. The safety of a country might be assured through the uniform inner policy, concerning safety measures and the economic system. The law defines the rules for providing safety and its legislative beginnings. The safety system is formed by legislative, executive and judicial powers, as well as social organisation and normal citizens, according to the law ${ }^{43}$. The general management over the public safety institutions in the Republic of Poland lies in the hands of the president. The government, however, guarantees the supervision directly to the national safety authorities. The ministries ensure the completion of programme, which take care of the interests of security objects. There are also Special Forces and funds responsible for the direct fulfillment of security tasks.

Through the individual or social point of view, a dangerous situation seems very blurry and unstable, depending on the sphere of human activity. The analysis of the dual category "danger- safety" requires a wider synthesis of humanistic knowledge. The realisation of the contemporary innovations in social practice allow current information and innovative methodological tools to be used in research, which enable a new logic of collaboration to be drawn up, which determinates security in its fresh quality, alias, the culture of security. The important factor of risk control

42 W. Kitler, Bezpieczeństwo narodowe RP. Podstawowe kategorie, uwarunkowania system, AON, Warszawa 2011, s. 78-89.

43 Ibidem, s. 191-242. 
in our life is our education and formation, which already starts to develop from our childhood, the so called culture of risk.

The culture of risk is nothing else than a system of terms, ideas, convictions, values, habits and traditions in comparision to knowledge and practice in security and risk management.

There is no harm in the idea of the need to connect the acceptable level of risk and safety. In different countries around the world, there are many institutions specialising in risk research, analysis etc. Some of them put more emphasis on the rational, analytical approach. Meanwhile, others insist on the importance of the subjective part of it. The second method, though, needs an adjustment of the existing classifications of risk. Most if all, it is important to focus on the evaluation, identification and preparation of the concept to manage the system (an individual) risks (and safety at the same time) during the whole time of its existence (life). Furthermore, we can take into account aother subjects, existing for more than one individual, like a family or a small organisation. The next step will be the risk/safety management model designed for big companies, society, country etc. This type of management can be described as a knowledge system and totality of contacts based on a philosophical approach to the topic, which allows optimal solutions to the different types of risk to be accepted. This wisdom consists in awareness development, as well as a harmonic connection between the participation of reason and heart (intuition) into the risk assessment. This means that every time we are forced to make a risky decision, our choice is conditioned by the subjective and objective factor ${ }^{44}$. The risk investigation might be divided in two main parts: 1) the summarisation of the knowledge, abilities and habits discovered in risk management till recent times; 2) the research of new models of security/risk management, its approval and popularisation among the public. Special attention should be cast on new approaches, ideas and methods, already present in non-linear dynamics, which might be useful in a risk/safety management sphere.

A prospect for the new, mathematic theory of safety and risk might be created, based on the already known research and experiences. The concept should be

44 D. Kahneman, Pułapki myślenia. O myśleniu szybkim $i$ wolnym, Media Rodzina, Warszawa 2012, s. 136. 
placed between political, strategic solutions and concrete, technical resources and systems. The results, which are already accomplished in this area, force us to change our point of view towards the anticipation and decrease of the unusual situations' effects. The recent conditions should allow us to create a new paradigm in the field of safety/risk management. Many important factor, which influence unusual situations are not taken into consideration when we talk about the practice. But, they must be mentioned when analysing a theory. This is how we can compare the impact of economic, ecological, psychological, legal, medical risks, etc.

It is vital to consider the state of safety of individuals or families, whose risk in society is growing every year. The culture of safety, compromise and prevention has gained a special meaning nowadays. The problem of adaptation into the society of risk touches many of its members. However, we are starting to adjust to this complex process. At the end of the day, the future of our society is not easy to predict and the risks will grow and develop even more fiercely. The risk sphere is growing bigger in these conditions, which requires a new approach to risk as a constant aspect of modern society.

Today, the term "risk" means not only the danger of failure, but also the possibility of a win. Not a hopeless wait, but rather a deliberate choice. Risk became one of the characteristics of society at the end of the twentieth and the beginning of the twenty-first century. However, the presented analysis still does not cover all the issues connected to the safety, lives and work of human beings in the society of risk.

\section{Bibliography}

1. Beck U., Spoteczeństwo ryzyka. W drodze do innej nowoczesności, SCHOLAR, Warszawa 2002.

2. Cempel Cz., Teoria i Inżynieria Systemów - zasady i zastosowania myślenia systemowego, Instytut Technologii Eksploatacji Państwowy Instytut Badawczy, Radom 2008.

3. Chandler D., Wprowadzenie do semiotyki, Oficyna wydawnicza VOLUMEN, Warszawa 2013.

4. Chyliński A., Podgladanie ryzyka. Dyktat zatożeń, PWN, Warszawa 2015. 
5. Giddens A., Konsekwencje nowoczesności, Wyd. UJ, Kraków 2008.

6. Giddens A., Stanowienie społeczeństwa. Zarys teorii strukturacji, Zysk i S-ka, Poznań 2003.

7. Gryz J., Strategia Bezpieczeństwa Narodowego Polski, PWN, Warszawa 2013.

8. Hofstede G., Kultury i organizacje, PWE, Warszawa 2007.

9. Holly R., Zarzadzanie ryzykiem - czyli czym? [w:] red. W. Sułkowska, Rynek ubezpieczeń. Wspótczesne problemy, wyd. Difin, Kraków 2013.

10. Kaczmarek T.T., Ryzyko i zarządzanie ryzykiem. Ujęcie interdyscyplinarne, Difin, Warszawa 2005.

11. Kaczorek T. i inni, Podstawy teorii sterowania, WNT, Warszawa 2005.

12. Kahneman D., Pułapki myślenia. O myśleniu szybkim i wolnym, Media Rodzina, Warszawa 2012.

13. Kitler W., Bezpieczeństwo narodowe RP. Podstawowe kategorie, uwarunkowania system, AON, Warszawa 2011.

14. Klamut R., Sommer H., Michalski K., Aktywność obywatelska we wspótczesnym społeczeństwie demokratycznym. Wybrane zagadnienia, Seiton, Kraków 2010.

15. Kozioł J., Gry decyzyjne w teorii i praktyce dowodzenia, AON, Warszawa 2001.

16. Kozioł J., Teoretyczne podstawy gier decyzyjnych $w$ doskonaleniu dowodzenia, AON, Warszawa 1999.

17. Krzyżanowski L.J., O podstawach kierowania organizacjami inaczej..., PWN, Warszawa 1999.

18. Luhmann N., Systemy społeczne. Zarys ogólnej teorii, tłum. Michał Kaczmarczyk, Nomos, Kraków 2007.

19. March J.G., Simon H.A., Teoria organizacji, PWN, Warszawa 1964.

20. Oxford Dictionary of English.

21. Raczkowski K., Sułkowski Ł., Zarządzanie bezpieczeństwem. Metody i techniki, Difin, Warszawa 2014.

22. Słownik terminów z zakresu bezpieczeństwa narodowego, AON, Warszawa 2008.

23. Zaleśkiewicz T., Przyjemność czy konieczność. Psychologia spostrzegania i podejmowania ryzyka, GWP, Gdańsk 2005. 